Studia Socialia Cracoviensia 6 (2014) nr 2 (11), s. 61-81

http://dx.doi.org/10.15633/ssc.774

\title{
Paulina Guzik
}

Uniwersytet Papieski Jana Pawła II w Krakowie

\section{REWOLUCJA, STATUS QUO CZY CHAOS - SPOEECZEŃSTWA WYBRANYCH KRAJÓW ARABSKICH CZTERY LATA Po ARABSKIEJ Wiośnie}

\begin{abstract}
Revolutionary, stagnant or chaotic? Societies of selected Arab states four years after the Arab Spring. The Spring of 2011 in the Arab world and its blooming revolutions were hopeful and precious. The whole world watched as angry masses of young Arabs toppled the regimes, ousting first Tunisia's Zine El Abedine Ben Ali and then Egypt's Hosni Mubarak. By the end of the year, with the help of American jetfighters, another bloody dictator was gone - Muamar Kaddafi no longer endangered the people of Libya. Social change was on the way - freedom of speech and freedom to vote were only among other prerogatives of the young civil societies. In 2012 all of those states had new governments and presidents. But something started to go wrong - in democratic elections islamists took over, not only destabilizing the countries, but fermenting newly born civil societies. In 2014, when the old power is back in Egypt, opposition leaders are being killed in Tunisia and Libya indicated sharia law, the world watches how "the class of 2011" - educated young Arabs that started the revolutions of 2011, will handle the changes. The article analyses changes observed within Arab societies in Egypt, Tunisia and Libya from December 2010 till December 2013. Analyses is based on „Time” magazine articles written about the Arab Spring Countries in the above dates.

Powstania arabskie zwane Arabską Wiosną były z początku odbierane jako wydarzenia niosące nadzieję na trwałe demokratyczne zmiany na Bliskim Wschodzie. Pokojowe protesty przyniosły w styczniu i lutym 2011 roku szybkie i bezkrwawe obalenie prezydenta Tunezji Zine El Abedine Ben Alego i wieloletniego autokratycznego przywódcy Egiptu - Hosniego Mubaraka. Pod koniec roku dzięki pomocy amerykańskiego lotnictwa kolejny dyktator - Muammar Kadafi - stracił władzę w Libii. Zmiany społeczne rozpoczęły się niemal natychmiast - zniesienie cenzury, wolność słowa i wolne wybory były ich najwyraźniejszymi sygnałami. W 2012 roku wszystkie trzy kraje miały nowe parlamenty i prezydentów. Szybko okazało
\end{abstract}


się jednak, że demokracja jest dla wszystkich - także dla fundamentalnych ruchów islamskich, które w ciemiężonych wcześniej społeczeństwach zdobyły pełnię władzy. Zamiast stabilizacji przyszedł chaos i kolejny bunt - liberalni aktywiści, którzy doprowadzili do rewolucji, rozpoczęli ponownie walkę - tym razem o to, by ich kraje nie przerodziły się z autokracji w teokrację. W 2014 roku do władzy w Egipcie ponownie doszli przedstawiciele obalonej w 2011 roku armii, w Tunezji morduje się liderów opozycji demokratycznej a w Libii obowiązuje islamskie prawo szariatu. Świat obserwuje zaś, czy „Klasa 2011”, która rozpoczęła falę powstań na Bliskim Wschodzie, rzeczywiście zmieni kraje regionu i ostatecznie odniesie sukces w kreowaniu społeczeństwa obywatelskiego. Artykuł analizuje zmiany zachodzące w społeczeństwach Bliskiego Wschodu w latach 2011-2013. Badania oparte są na analizie zawartości mediów - amerykańskiego wydania magazynu „Time”.

Keywords Arab Spring, Middle East, democratic revolution, Arab society, "Time"

Arabska Wiosna, Bliski Wschód, rewolucja demokratyczna, społeczeństwo arabskie, magazyn „Time”

9 czerwca 2014 roku Abdel Fatah Al-Sisi został zaprzysiężony na prezydenta Egiptu. Zdobywając 9 dni wcześniej 96 proc. głosów, mówił w Zgromadzeniu Ogólnym Najwyższego Sądu Konstytucyjnego w Kairze:

W długiej historii, sięgającej tysiące lat wstecz, nasza ojczyzna nie była świadkiem demokratycznego przekazania władzy. Teraz po raz pierwszy prezydent elekt uścisnął dłoń odchodzącego prezydenta i razem podpisują dokument transferu władzy w tych niewidzianych dotąd okolicznościach ${ }^{1}$.

Rzeczywiście, pierwszy raz nowy prezydent żegnał odchodzącego. Jednak sposób, w jaki doszło do zdobycia stanowiska prezydenta przez generała Al-Sisi, nie miał wiele wspólnego z demokratycznym transferem władzy. Generał Abdel Fatah Al-Sisi, przedstawiciel „starej gwardii” obalonego przez masowe protesty w 2011 roku prezydenta Hosni Mubaraka, doszedł do władzy za pomocą zamachu stanu. Obalił pierwszego (faktycznie) demokratycznie wybranego przez egipcjan prezydenta - Mohameda Morsiego. Rewolucja zatoczyła koło - na życzenie samych Egipcjan władza wojskowa ponownie wkroczyła na egipskie salony.

Protesty, które wstrząsnęły krajami arabskimi na początku 2011 roku, nazywane są na świecie Arabską Wiosną. Cztery lata od rewolucji wielu badaczy nazywa je już jednak islamską zimą albo straconą wiosną. W Egipcie i Tunezji liberałowie, którzy protestowali przeciwko dyktatorom, nie potrafili zjednoczyć się na tyle, by w wyborach prezydenckich w 2012 roku wystawić jednego kandydata. Szyki zwarły partie islamskie, przez 40 lat działające w ukryciu, represjonowane przez gabinety dyktatorów. W Egipcie we wspomnianych pierwszych po Arabskiej Wiośnie demokratycznych wyborach na prezydenta wygrał przedstawiciel Bractwa Muzułmańskiego Mohamed Morsi. Jego partia zdobyła także większość miejsc w parlamencie. W Tunezji wybory wygrała partia Ennahda - także partia

\footnotetext{
1 www.edition.cnn.com/2014/06/08/world/africa/egypt-presidential-election/ (11.08.2014).
} 
islamska. W Syrii dyktator nie oddał władzy, krwawo tłumił protesty zimą i wiosną 2011 roku. Dziś w Syrii trwa regularna wojna domowa, na której najwięcej zyskali fundamentaliści islamscy. W czerwcu 2014 roku ogłosili oni powstanie islamskiego państwa - kalifatu na terenach zachodniego i północno-zachodniego Iraku i wschodniej Syrii. W Libii w dwa lata po obaleniu dyktatora Muamara Kaddafiego, 4 grudnia 2013 roku, wprowadzono prawo szariatu jako obowiązujące na terenie całego kraju.

Młodzi Egipcjanie i Tunezyjczycy, którzy najliczniej protestowali na placach i ulicach swoich krajów zimą i wiosną 2011 roku, po ogłoszeniu wyników wyborów, w których zwyciężyły partie islamskie, przyznali, że islamiści „ukradli” im rewolucję, że tylnymi drzwiami weszli w lukę, jaka pozostała po niemal 40 latach dyktatorskich rządów. W Libii natomiast, gdzie dyktator został obalony z pomocą amerykańskich bombowców, panuje chaos i bezprawie, a klanowe i polityczne frakcje wciąż nie podzieliły się ani władzą, ani największym libijskim bogactwem - złożami ropy naftowej.

Społeczeństwo arabskie dokonało niemal niemożliwego - bez wyrazistych liderów, bez arabskiego Wałęsy, Havla czy Mandeli tłumy stanęły twarzą w twarz z reżimem i - wszelkimi pokojowymi środkami - od demonstracji po media społecznościowe takie jak Facebook i You Tube, zdjęły z piedestałów dyktatorów. Czy znając realia roku 2014, można jednak mówić o społecznej rewolucji? Jeśli podczas dyktatorskich rządów reżimów Mubaraka, Ben Alego czy Kaddafiego wykluczenia społecznego doświadczało wiele grup, takich jak choćby działacze opozycyjni czy islamskie ruchy religijne, to czy teraz można mówić o powstaniu społeczeństwa obywatelskiego? Czy arabskie społeczeństwa faktycznie mogą cieszyć się większymi niż dotychczas swobodami i wolnością słowa? Czy zmniejszył się poziom wykluczenia społecznego, skoro wielu aktywistów zakazanych ruchów może teraz legalnie działać na terenie Egiptu czy Libii? Na te pytania szukano odpowiedzi w badaniach, których wyniki przedstawiono w artykule. Badania skupiają się na społeczeństwach trzech krajów - Egiptu, Tunezji i Libii. Mowa o wolnościach obywatelskich w targanej wojną domową Syrii nie ma uzasadnienia, a sytuacja społeczno-polityczna w tym kraju wymaga osobnej analizy. W krajach takich jak Jemen czy Bahrajn natomiast rewolucje można nazwać częściowymi - w Jemenie ustąpił prezydent, ale jego partia pozostała przy władzy, w Bahrajnie natomiast wciąż rządzi dotychczasowy monarcha, który w wyniku protestów zaproponował rodakom pewne swobody obywatelskie.

\section{Metodologia}

Metoda badawcza zastosowana w artykule to analiza zawartości mediów. Autorka dokonała całościowej analizy zawartości amerykańskiego wydania magazynu „Time” w okresie grudzień 2010 - grudzień 2013. Magazyn „Time” ” jest najbardziej znanym na świecie tygodnikiem opinii. Ma swoje wydania w Stanach Zjednoczonych, Europie (to samo wydanie na Afrykę i Bliski Wschód), Azji, a także wydanie „Południowy Pacyfik” obejmujące m.in. Australię. Żaden inny magazyn na świecie nie ma tak szerokiego wachlarza wydań, żaden nie ma takiego nakładu - czytelnictwo to 25 milionów egzemplarzy na całym świecie. Ze względu na prestiż i popularność amerykańskiego wydawnictwa, właśnie „Time” jest źródłem niniejszej analizy. Ponadto magazyn „Time” , w przeciwieństwie do wielu agencji i mediów na świecie, ma swoich stałych korespondentów w Egipcie, 
Turcji czy Izraelu. Z redakcją współpracują najlepsi fotoreporterzy wojenni. Jedni i drudzy niewątpliwie przyczynili się do pogłębionej analizy wydarzeń na Bliskim Wschodzie w latach 2010-2013.

W celu zbadania, czy społeczeństwa arabskie faktycznie przeszły rewolucję i zmniejszyły zjawisko wykluczenia społecznego, autorka zanalizowała 276 artykułów w magazynie „Time” z okresu grudzień 2010 - grudzień 2013. Analizowano artykuły, w których pojawiały się słowa: Tunezja, Egipt, Syria, Libia, Bliski Wschód. 126 artykułów było tekstami redakcyjnymi, 52 pojedynczymi cytatami dotyczącymi badanej problematyki, 80 tekstami agencyjnymi. Najwięcej - 79 artykułów ukazało się w dziale newsowym magazynu (Briefing), 77 w dziale zagranicznym (Word), 12 w dziale krajowym (Nation), 29 w dziale komentatorskim, a 6 w dziale edytorskim. Krótkie notki newsowe, agencyjne, pojedyncze cytaty dotyczące danej problematyki, a także edytoriale redaktora naczelnego były poddawane wyłącznie analizie ilościowej, nie jakościowej.

98 materiałów dziennikarskich dodatkowo poddano badaniu stopnia ich uwidocznienia. Stopień uwidocznienia odzwierciedla wagę, jaką redakcja przypisywała tekstowi. Przyjęto dziesięciostopniową skalę (od 0 do 9 punktów), w której do 3 punktów przyznawano kolejno za: a) miejsce publikacji, b) zastosowane wyróżniki graficzne, c) atrakcyjny tytuł materiału dziennikarskiego. Ze względu na specyfikę analizy kierowano się następującymi zasadami:

Ad a) - 3 punkty przyznawano za tzw. cover story - historię okładkową; 2 punkty - za materiał zapowiedziany w spisie treści lub na pierwszej stronie gazety; 1 punkt - za materiał umieszczony w stałych działach.

Ad b) - 3 punkty przyznawano w przypadku opatrzenia materiału dziennikarskiego zróżnicowanymi ilustracjami (zdjęcie uznanego fotografa, grafika, mapy); 2 punkty - za mnogość ilustracji; 1 punkt - za jedną ilustrację.

Ad c) - 3 punkty przyznawano, gdy tytuł zawierał ładunek emocjonalny zachęcający do lektury, artykuł zawierał lead i śródtytuły; 2 punkty za rozbudowany lead i śródtytuły; 1 punkt - gdy wystąpił albo lead, albo śródtytuły.

Największą objętość miały w analizie artykuły publicystyczne, relacje z miejsca wydarzeń i reportaże. One też opatrzone były największą liczbą zdjęć uznanych fotografów (dla „Time” wydarzenia rewolucyjne fotografowali m.in. światowej sławy fotoreporterzy Yuri Kozyrev, Peter Hapak, Alessio Romenzi).

Analizowane artykuły dotyczyły w największym stopniu komentowania wydarzeń bieżących - artykuły newsowe lub na podstawie bieżących wydarzeń zajmowały 37,44 proc. analizowanych tekstów (107 publikacji), 26 publikacji (9, 42 proc.) to artykuły publicystyczne. W badanym okresie ukazało się 13 relacji z miejsca wydarzeń (4,71 proc.), 6 reportaży (2,17 proc.), 33 felietony (11,96 proc.) i 12 komentarzy redakcyjnych (4,35 proc.).

Rewolucja w krajach islamskich była ważnym wydarzeniem dla zachodnich dziennikarzy, wydawców i odbiorców mediów. Aż 17 okładek magazynu „Time” w badanym okresie było poświęconych wydarzeniom na Bliskim Wschodzie.

O wadze tematyki dla czasopisma świadczy fakt, że były one najczęściej pisane przez uznanych ekspertów (takich jak Fareed Zakaria, autor programu GPS w CNN i stały komentator gazety), szefów działów (szefa działu zagranicznego Bobby’ego Ghosha czy szefa biura „Time” w Waszyngtonie Michaela Crowleya) i wybitnych ekspertów w dziedzinie Bliskiego Wschodu i amerykańskiej polityki zagranicznej (Richarda Hassa, Shadiego Hamida, Zbigniewa Brzezińskiego). Spośród tekstów redakcyjnych 11,96 proc. zostało 
napisanych przez uznanych ekspertów związanych z gazetą, 7,97 proc. przez korespondentów zagranicznych, 5,8 proc. przez szefów działów. Fakt, że artykuły w tak dużej części pisane były przez doświadczonych dziennikarzy lub ekspertów w dziedzinie stosunków międzynarodowych, mających wiedzę o polityce i społeczeństwie w regionie Bliskiego Wschodu, podnosi wartość poniższej analizy.

Magazyn „Time” ma korzenie amerykańskie. Został założony w 1923 roku w Nowym Jorku i mimo względnej niezależności swoich wydań międzynarodowych pozostaje pod wpływem redaktora naczelnego - w latach 2006-2013 był nim Richard Stengel, obecnie wysoko postawiony doradca w Departamencie Stanu USA. Polityka zagraniczna Stanów Zjednoczonych była więc najczęściej analizowanym tematem wśród artykułów innych niż newsowe w magazynie - spośród 98 artykułów poddanych analizie jakościowej 38 traktowało o amerykańskiej polityce zagranicznej wobec kraju lub regionu, 26 opisywało wydarzenia w kontekście bieżących wydarzeń politycznych, 21 - w kontekście społecznym, w tym tzw. human story, a 5 opisywało lokalną organizację polityczną. Przemiany społeczne w danym kraju lub regionie były tematem głównym 14 artykułów (14,2 proc. artykułów poddanych analizie jakościowej), 29,6 proc. artykułów poruszało wątek przemian społecznych. Sposób, w jaki pisano o przemianach społecznych, i stosunek do tych przemian opisywany jest w dalszej części artykułu.

\section{Historia REWOLUCJI}

17 grudnia 2010 roku Mohamed Bouazizi, 26-latek z małego miasta Sidi Bouzid 300 $\mathrm{km}$ na południe od Tunisu, podpalił się przed budynkiem miejskich władz. Od wielu lat ciężko pracował na swoim straganie, próbując zarobić na chleb dla matki i pięciorga rodzeństwa. W grudniowy poranek policjanci skonfiskowali jego wózek z warzywami pod pretekstem braku rejestracji, a policjantka publicznie znieważyła chłopaka, uderzając Mohameda w twarz. Młody człowiek w akcie desperacji poszedł wprost do siedziby lokalnych władz, żądając spotkania z burmistrzem. Gdy mu odmówiono, wypełnił swoją makabryczną groźbę wykrzyczaną w budynku urzędu i podpalił się przed jego bramą. Ciężko poparzony, trafił do szpitala.

Tego popołudnia inni sprzedawcy i ludzie z miasteczka dołączyli do rodziny Bouazizich przed budynkiem ratusza. Kuzyn Mohameda zamieścił w internecie wideo z demonstracji. Media społecznościowe i arabska telewizja satelitarna Al Jazeera szybko podchwyciły temat. 28 grudnia prezydent Zine El Abedine Ben Ali odwiedził poparzonego chłopaka w szpitalu w nadziei, że dzięki temu protesty się uspokoją. Jednak po śmierci Mohameda Bouaziziego (4 stycznia) protesty osiągnęły apogeum. 14 stycznia, 10 dni po śmierci Mohameda, Ben Ali uciekł z Tunezji - jego 23-letnie rządy się skończyły. Mohamed stał się dla Tunezyjczyków męczennikiem.

Ekonomiczne możliwości w zamian za polityczne wolności - taki był przez lata niepisany układ tunezyjskiej władzy ze społeczeństwem. W ostatnich latach wskaźniki korupcji wciąż rosły, podobnie jak inflacja i stopa bezrobocia wśród młodych ludzi.

Najgorsza była sytuacja ludzi młodych (przed 30. rokiem życia) - nazywani „straconym pokoleniem" nie mieli pracy i perspektyw na przyszłość - ani zawodową, ani osobistą. 
Kiedy globalna ekonomia zwolniła w 2008 roku, lokalny rynek pracy w Tunezji skurczył się - aż 25 proc. młodych Tunezyjczyków pozostawało bez pracy. Polityka edukacyjna prezydenta Ben Alego produkowała każdego roku dziesiątki tysięcy wykwalifikowanych młodych ludzi, ale wielu z nich stawało przed perspektywą wielu lat na bezrobociu. W obliczu takiej sytuacji w przeszłości wielu Tunezyjczyków wyjechałoby za chlebem za granicę, ale europejski rynek pracy pełny był pracujących poza krajem Polaków czy Rumunów. Tunezyjczycy zostali więc w kraju i postanowili walczyć o swoje prawa².

Dla młodych ludzi w Tunezji Bouazizi stał się symbolem - magazyn „Time” cytuje mieszkańca miasteczka Sidi Bouzid: „Jestem absolwentem informatyki i nie miałem pracy przez 4 lata. [...] Jaka jest moja przyszłość? Wszyscy skończymy jak Bouazizi, jeśli nasze nadzieje zostaną pogrążone"3.

Fareed Zakaria, felietonista magazynu „Time” i jeden z najbardziej znanych ekspertów polityki międzynarodowej, pisał 28 lutego 2011 roku:

Centralnym punktem kryzysu na Bliskim Wschodzie jest potężna liczba młodych ludzi. Około 60 proc. populacji regionu jest poniżej 30 roku życia. Te miliony młodych ludzi mają aspiracje, które muszą spotkać się ze zrozumieniem, a reżimy obecnie rządzące niewiele w tej kwestii robią. Żądania protestujących zostały oddalone przez reżimy jako te, które wspierają fundamentalizm albo są produktem wpływu międzynarodowego. Ale tak naprawdę to są protesty, które wyrosły na gruncie lokalnym i raczej nastręczyły kłopotów Zachodowi, wstrząsając starymi reżimami.

Czego protestujący chcieli przede wszystkim, to być traktowani jak obywatele, nie przedmioty. W ankiecie przeprowadzonej w 2010 roku wśród młodzieży Bliskiego Wschodu marzeniem numer 1 młodych ludzi w 9 krajach było, by żyć w wolnym kraju, choć praca i chęć życia w dobrobycie i w nowoczesnym społeczeństwie także były stawiane bardzo wysoko ${ }^{4}$.

W Egipcie, podobnie jak w Tunezji, przez ostatnie lata prezydent Hosni Mubarak - w 2011 roku 83-letni generał szykujący się do świętowania czterdziestolecia sprawowania władzy - zaczął wprowadzać plan reform ekonomicznych, obiecując modernizację państwa i miejsca pracy. Jednak koszty życia zamiast maleć - rosły, a pracy, szczególnie dla młodych - ubywało. Korupcja rządowa i represje przenikały już wszystkie poziomy państwowości ${ }^{5}$. Dzięki internetowi i satelitarnej telewizji Egipcjanie błyskawicznie dowiedzieli się o tym, co dzieje się w Tunezji. Tunezyjczycy udowodnili zaś, że bez wielkiego przelewu krwi (sprzyjająca demonstrantom armia tunezyjska nie pacyfikowała demonstracji) można obalić dyktatora.

Egipcjanie także mieli swojego męczennika. Był nim Khaled Said, 28-letni informatyk skatowany przez policję w jednej z kafejek internetowych w Aleksandrii. Wael Ghonim, dyrektor marketingu firmy Google mieszkający w Kairze, założył stronę w serwisie Facebook: „Wszyscy jesteśmy Khaledem Saidem”. Strona szybko stała się tubą aktywistów,

2 V. Walt, Tunisia's nervous neighbors watch the Jasmine Revolution, dz. cyt., s. 24.

3 R. Abouzeid, Postcard: Sidi Bouzid. Visiting the birthplace of the Jasmine Revolution, „Time” 7.02.2011, s. 8 .

F. Zakaria, Why it's different this „Time”, „Time” 28.02.2011, s. 28-32.

A. Hauslohner, On the Arab street. Rage is contagious, „Time” 7.02.2014, s. 36. 
dzięki niej tysiące ludzi dowiadywało się o planowanych demonstracjach. Pierwsza odbyła się 25 stycznia 2011 roku. Wypadał wtedy Dzień Policji - jednej z najbardziej znienawidzonych przez społeczeństwo egipskie instytucji, znanej ze swojej brutalności. Cytowany przez magazyn „Time” Shadi Taha (członek partii Ghad) i jego znajomi aktywiści myśleli, że zgromadzą około 200 protestujących. Dwa tygodnie przed planowanym w Kairze protestem byli jednak świadkami ucieczki dyktatora z Tunezji: „To dało nam nadzieję, że to może wydarzyć się także w Egipcie"6. 25 stycznia na ulicach Kairu stawiło się kilkadziesiąt tysięcy ludzi. 1 lutego na place miast wyszły już miliony ludzi w całym Egipcie. Na samym placu Tahrir (placu Wolności) według telewizji Al Jazeera było ponad milion osób, ale ta liczba nie została nigdy potwierdzona.

8 lutego plac Tahrir wypełniony przez protestujących miał też swojego nowego bohatera: był nim Weal Ghonim, dyrektor Google, twórca strony „Wszyscy jesteśmy Khaledem Saidem”. Dwa dni po pierwszym proteście, 25 stycznia, Ghonim został aresztowany przez państwowe służby bezpieczeństwa i był przetrzymywany przez 12 dni. Wypuszczony 7 lutego, 30-letni Ghonim napisał na Tweeterze: „Wolność jest błogosławieństwem, za które warto walczyć". Tego wieczora dał wywiad popularnej egipskiej stacji satelitarnej Dream TV. Kiedy pokazano mu montaż zdjęć około 300 protestujących, którzy zginęli podczas demonstracji, Ghonim wybuchł płaczem i wyszedł ze studia. Z człowieka znanego tylko garstce aktywistów stał się plakatowym symbolem powstania. Około 130 tysięcy osób dołączyło wówczas do strony poświęconej mu na portalu Facebook: „Upoważniam Waela Ghonima, by mówił w imieniu egispkich rewolucjonistów"7. Po tym, gdy 8 lutego przemówił do setek tysięcy demonstrantów na placu Tahrir, napisał na swoim profilu internetowym: „Nie jestem bohaterem, OK? Nie jestem bohaterem. Jestem zwykłą osobą. Bohaterami są ci na ulicach"8.

Rozmiary protestów, które tak szybko jak wirus z Tunezji przeniosły się do Egiptu i innych państw Bliskiego Wschodu, zaskoczyły samych mieszkańców: „Nie spodziewałem się tak wielu ludzi”9 mówił magazynowi „Time” jeden z uczestników demonstracji, Ahmed Osama. Nawet ludzie zaangażowani w działalność opozycyjną mówili, że to największe protesty, jakie widzieli za swojego życia.

Spośród 98 artykułów poddanych analizie 29 dotyczyło lub poruszało wątek przemian społecznych na Bliskim Wschodzie po rewolucjach. Niemal połowa - 44,8 proc. - opisywała zmiany zachodzące w społeczeństwie pozytywnie, a 37,9 proc. neutralnie. Jedynie 5 artykułów (17,2 proc.) prezentowało zmiany zachodzące w społeczeństwie negatywnie. Z prawie 50 proc. $(44,8)$ artykułów, w których wspomniany był wątek przemian społecznych, można było wnioskować, że wydarzenia rewolucyjne w danym kraju wpłyną pozytywnie na społeczeństwo danego kraju lub regionu lub zmniejszą wykluczenie społeczne. 27,6 proc. autorów było zdania, że wydarzenia w danym kraju będą prowadzić do negatywnych przemian i podziałów w społeczeństwie, a nawet zwiększą wykluczenie społeczne.

Taki generalnie pozytywny obraz rewolucji (szczególnie w jej pierwszej fali) w zachodnich mediach spowodowany był między innymi tym, że rewolucje de facto zorganizowane

6 B. Ghosh, The revolutionaries: how a loose coalition of veteran activists and rookie protesters combined to create the Middle East's most unusual uprising, „Time” 14.02.2011, s. 38-39.

7 B. Ghosh, Revolution delayed, „Time” 21.02.2011, s. 35.

8 Briefing, The moment, „Time” 21.02.2011, s. 17.

9 A. Hauslohner, On the Arab street. Rage is contagious, dz. cyt., s. 36. 
były przez ludzi niezaangażowanych politycznie. Na pierwszych wiecach w Tunezji czy Egipcie nie widać było przedstawicieli islamistów, fundamentalistów czy opozycyjnych działaczy powracających z emigracji. Według reporterów magazynu „Time” bohaterowie rewolucji to ludzie, którzy po raz pierwszy w życiu brali udział w takich protestach. Zachodnim mediom przypominało to aksamitną, bezkrwawą rewolucje w Europie w 1989 roku.

Wspomiany aktywista egipski Shadi Taha mówił reporterce „Time”: „Nazywaliśmy ich cichą masą - masą niezaangażowaną w politykę, a już na pewno niezaangażowaną w Bractwo Muzułmańskie”. W artykule czytamy: „nie można powiedzieć, że długo cierpiące grupy opozycyjne w Egipcie pozostały zupełnie na uboczu: prominentni działacze byli widziani, jak maszerowali z tłumami. Ale to nuworysze mieli na nie największy wpływ. Można to było wywnioskować z haseł, jakie wykrzykiwali”10.

O tym, że to nuworysze stworzyli arabskie rewolucje, świadczy fakt, że spośród 98 szczegółowo analizowanych jakościowo artykułów w 30 pojawiały się historie poszczególnych ludzi (tzw. human story), z czego ponad połowa (18 artykułów) bazowała na historiach ludzi nieznanych szerszej publiczności. To właśnie ci zwykli ludzie, nieznani liderzy polityczni czy inne osoby publiczne, stworzyli arabskie rewolucje (z drugiej strony ci sami zwykli ludzie cierpią największe represje i dramaty w ogarniętej wojną domową Syrii).

Powody, dla których Arabowie masowo wyszli na ulice, wszędzie, mimo ogromnych różnic między opisywanymi krajami, były podobne:

- $\quad$ wzrastające ceny żywności,

- bezrobocie młodych,

- $\quad$ sprawy więźniów politycznych (m.in. walka o delegalizację tortur),

- dyskryminacja mniejszości.

Zatem społeczeństwa arabskie walczyły o zmniejszenie wykluczenia społecznego i o obywatelskie wolności. 11 lutego, w dniu, w którym Hosni Mubarak ustąpił z urzędu prezydenta Egiptu, prezydent Barack Obama wystąpił w Białym Domu ze specjalnym przemówieniem:

Niewiele jest momentów w naszym życiu, kiedy mamy przywilej bycia świadkami tworzenia się historii. To jest jeden z tych momentów. [...] Ludność Egiptu przemówiła, ich głosy zostały usłyszane, Egipt nigdy nie będzie już taki sam. Ustępując, prezydent Hosni Mubarak odpowiedział na głód zmian wyrażany przez Egipcjan. Ale to nie koniec egipskiej transformacji. To początek. Jestem pewny, że trudne dni przed nami, wiele pytań pozostaje bez odpowiedzi. Ale jestem pewien, że ludzie Egiptu znajdą odpowiedzi, zrobią to pokojowo, konstruktywnie i w duchu jedności, który towarzyszył im przez ostatnie tygodnie. Egipcjanie jasno dali do zrozumienia, że nic bardziej prawdziwego niż demokracja nie poprowadzi ich naprzód ${ }^{11}$.

Zachód zaraził się bliskowschodnim optymizmem, bijącym od tysięcy radosnych młodych ludzi na placach i ulicach Egiptu, Tunezji i innych krajów arabskich. Już w maju 2011 roku magazyn „Time” umieścił aż 5 osób związanych z ruchami wolnościowymi na Bliskim Wschodzie na liście „Time 100” - 100 najbardziej wpływowych ludzi na świecie.

10 A. Hauslohner, On the Arab street. Rage is contagious, dz. cyt., s. 36.

11 www.whitehouse.gov/the-press-office/2011/02/11/remarks-president-egypt (14.08.2014). 
Listę otwiera Wael Ghonim, aktywista egipski, twórca stron w mediach społecznościowych, które zachęcały do protestów. Mohamed El Baradei, laureat pokojowej nagrody Nobla, pisał o nim tak:

Wael Ghonim ucieleśnia młodych, którzy stanowią większość egipskiego społeczeństwa - młody mężczyzna, który doskonalił się i stał się dyrektorem w Google, ale, tak jak wielu w jego generacji, pozostał apolityczny wobec braku nadziei, że coś może się zmienić w społeczeństwie, przez dekady chowanym w kulturze strachu. [...] To, co zrobił Wael i młodzi Egipcjanie, rozlało się jak ogień przez arabski świat. Dziękuję, Wael. Dziękuję, młodzi Egipcjanie ${ }^{12}$.

Na 26 miejscu listy znalazł się Fathi Terbil, libijski prawnik, obrońca praw człowieka i rodzin skrzywdzonych przez reżim Kaddafiego, na miejscu 55 Maggie Woodward - amerykańska generał, dowódca nalotów NATO na Libię, na miejscu 64 znalazł się El General, tunezyjski raper zachęcający do rewolucji swoimi piosenkami, a na miejscu 86 - Ayman Moyheldin, ówczesny dziennikarz telewizji Al Jazeera, korespondent stacji w Kairze.

Ukoronowaniem zachodniego optymizmu wobec wydarzeń Arabskiej Wiosny, a jednocześnie nagrodą dla milionów demonstrantów od Tunezji przez Syrię było nadanie tytułu Człowieka Roku 2011 magazynu „Time” Protestującemu (The Protester). Richard Stengel, ówczesny redaktor naczelny magazynu, napisał:

Protestujący zaznaczyli powstanie nowej generacji. W Egipcie $60 \%$ populacji to ludzie poniżej 25 roku życia. Technologia odegrała tu znaczącą rolę, ale to nie była rewolucja technologiczna. Media społecznościowe nie spowodowały powstania tych ruchów, ale sprawiły, że ruchy te żyły i pozostały wzajemnie poinformowane. Technologia pozwoliła nam oglądać i rozniosła wirusa protestów, ale to nie była rewolucja wirtualna, to była rewolucja ludzka, serc i umysłów, najstarszej technologii ze wszystkich. Za uwiecznienie i podkreślenie globalnego odczucia niespełnionych obietnic, za zniszczenie rządów i konwencjonalnej mądrości, za połączenie najstarszych z technik z najnowszymi technologiami, by oświetlić ludzką godność, i wreszcie za skierowanie planety na bardziej demokratyczną, a co za tym idzie także bardziej niebezpieczną ścieżkę w XXI wieku, Protestujący jest człowiekiem Roku magazynu „Time” w 2011 roku $^{13}$.

\section{Pierwsza fala rewolucji - pozytywne zmiany W STRUKTURACH PAŃSTWOWYCH I SPOEECZNYCH}

W powszechnym przekonaniu jeszcze na początku 2011 roku Egipcjanie byli wycofani, potulni wobec religii i hierarchii. Ale pod koniec stycznia ulice Kairu czy Aleksandrii były pełne energetycznych tłumów ludzi z różnych stanów społecznych, także kobiet. Wszyscy oni z determinacją chcieli wpłynąć na swój los. Zakaria łączy to z cechami narodowymi Efipcjan:

12 M. ElBaradei, Wael Ghonim - spokesman of a revolution, „Time”, www.content.time.com/time/specials/ packages/article/0,28804,2066367_2066369_2066437,00.html (30.06.2014).

13 R. Stengel, The Protester - editors note, „Time” 26.12.2011, s. 53. 
„Egipcjanie nigdy nie byli tak spokojni, jak się wydawało. Egipskie społeczeństwo zapoczątkowało wiele ruchów społecznych, od radykalizmu islamskiego przez arabski nacjonalizm aż po marksizm i liberalizm. Jednak od lat 50. egipski reżim tłumił aktywność społeczną, zamykając partie polityczne, gazety, więżąc polityków, przekupując sędziów i uciszając intelektualistów. Przez trzy ostatnie dekady Egipt był miejscem, gdzie wydano zaledwie kilka poważnych książek, uniwersytety były monitorowane, gazety ostrożnie podążały za linią partii, a ludzie uważali na to, co mówią publicznie. Przez ostatnie 20 lat wojna $z$ terrorystami islamskimi [...] pozwoliła Mubarakowi naciskać jeszcze mocniej na egipskie społeczeństwo w imię bezpieczeństwa"14.

Tak o Egipcjanach pisał w lutym 2011 Fareed Zakaria. Rzeczywiście, młodzi Egipcjanie i Tunezyjczycy zrobili w kilka tygodni to, co nie udało się ich rodzicom przez 30 lat działania w podziemnej i mocno inwigilowanej opozycji. W pierwszej fazie rewolucji nazywano ich nawet pokoleniem cudów, bo w obliczu optymizmu, jaki rozlał się wówczas na Bliskim Wschodzie, tak właśnie to wyglądało - jak cud.

Przez lata zachodni eksperci w dziedzinie Bliskiego Wschodu nazywali arabską młodzież sfrustrowaną i nieskuteczną; nie dostrzegali w nich potencjału. Ale ankieta przeprowadzona wśród młodych ludzi z 9 krajów arabskich opublikowana w 2010 roku przez firmę PR Asda’a Burson-Marsteller pokazała, że uznali oni demokrację za większy priorytet niż infrastruktura, możliwość edukacji na najlepszych uczelniach czy nawet równe płace ${ }^{15}$.

Działalność młodych demokratów egipskich i tunezyjskich warta jest zauważenia także z innego względu - nie tylko obalili oni dyktatora, ale rozszerzyli swój polityczny bunt na kampanię świadomości społecznej. Ahmed Khalil, potomek zamożnej rodziny egipskich biznesmenów i weteran z placu Tahrir, jeden z twórców grupy Przyjaciele Rewolucji stworzonej na Facebooku wydrukował na przykład ulotki, na których napisał, jak zachowuje się Egipcjanin żyjący poza dyktaturą, w demokratycznym kraju, o który każdy tak samo musi dbać. Przykładowe sugestie na ulotkach to: nie śmieć, nie używaj klaksonu bez powodu, nie płać łapówek, nie pozwól oficerowi policji upokorzyć kogoś w twojej obecności, nie zaczepiaj dziewczyn na ulicy, znaj swoje prawa, bądź pozytywny, szanuj opinie innych ${ }^{16}$. Jeśli małymi krokami można osiągnąć pozytywną zmianę w społeczeństwie, to niewątpliwie społeczeństwo Egiptu choć częściowo dostosowało się do tych apeli - podczas protestów młodzi ludzie zbierali tony śmieci i sami uciszali wszczynane podczas demonstracji bójki.

Omar Mohanna, szef Suez Cement Co., jednej z największych firm w Egipcie, mówił reporterowi „Time”:

Mój syn jest wziętym prawnikiem w Londynie. Przyjechał, by wziąć udział w protestach. Poszliśmy całą rodziną. Nigdy czegoś takiego nie widziałem. Młodzi ludzie podnoszący śmieci. Próbowałem znaleźć jakiś śmieć, by się dołączyć, ale nie znalazłem żadnego, tak było czysto. Moja żona jest bardzo świecką osobą, ale widziałem ją w intensywnej rozmowie z kobietą w czarnej chuście. To było niesamowite ${ }^{17}$.

14 F. Zakaria, The revolution, „Time” 14.02.2011, s. 29.

15 B. Ghosh, Rage rap and revolution, „Time” 28.02.2011, s. 33-34.

16 B. Ghosh, Rage rap and revolution, s. 37.

17 J. Klein, Cairo's unsettled spring, „Time” 18.04.2011, www.content.time.com/time/magazine/article/0,9171 ,2063873,00.html (30.06.2014). 
Jednak w tym samym tekście autor zwraca uwagę na to, że euforia rewolucji nie może trwać wiecznie, że Egipcjanie będą chcieli egzekwować od nowych władz konkretne rezultaty ich działań na rzecz poprawy sytuacji społecznej: „Musimy doprowadzić to sytuacji, że ludzie będą jedli chleb, a nie grzebali w śmieciach" mówił Wael Ghonim, dyrektor w Google, którego strona na portalu Facebook pomogła rozniecić protesty. «Chleba, nie śmieci», powinno stać się naszym następnym hasłem"18.

Rewolucja w swojej pierwszej fazie była zatem nie tylko próbą obalenia dyktatur, ale też zmiany relacji społecznych w krajach arabskich, a także pojmowania Bliskiego Wschodu przez społeczeństwa zachodnie. Paul Danahar, wieloletni dziennikarz BBC argumentuje: „ "Arabowie» nigdy nie byli traktowani jako zbiór indywidualistów. Świat skupiał się na tym, co tych ludzi łączyło. Teraz musimy skupić się na tym, co ich różni”19.

Właśnie z różnic między państwami i społeczeństwami, a także między reżimami wynikał różny przebieg Arabskiej Wiosny w wielu krajach.

W Libii, co nie było żadnym zaskoczeniem, przywódca-despota nie planował rozmów z założycielami internetowych stron nawołujących do demokratycznych przemian. Podczas protestu w Trypolisie, nazwanego Dniem Gniewu, otworzył ogień do demonstrantów, zabijając co najmniej 300 osób. Dokładna liczba jego ofiar nie jest znana - Libia natychmiast została zamknięta dla zagranicznych dziennikarzy. 22 lutego w przemówieniu do narodu przywódca ogłosił, że każdego, kto wystąpi przeciwko jego rządowi i wykaże się nielojalnością, czeka śmierć. Wobec miażdżącej przewagi wojsk rządowych i - przede wszystkim - posiadania przez libijskie wojsko floty lotniczej rebelianci byli praktycznie bez szans. Uratowała ich rezolucja ONZ nr 1973, którą rozpoczęła się operacja wojsk zachodniej koalicji „Oddysey Dawn” (Wschód Odysei). Operacja rozpoczęła się 19 marca 2011 roku, 31 marca dowództwo nad nią przejęło NATO. Po pół roku walk i nalotów jesienią 2011 roku siły rebeliantów kontrolowały większość kraju. Ostatnim i symbolicznym bastionem lojalistów zdobytym 20 października przez rebeliantów była Syrta - rodzinne miasto dyktatora. Tego samego dnia, 20 października 2011 roku Muammar Kadafi został schwytany i zabity. Rządy kolejnego despoty na Bliskim Wschodzie były zakończone.

Za dyktatury Kadafiego sytuacja społeczeństwa w tym bogatym kraju była przerażająca. W kraju o ogromnej powierzchni (jak Francja, Hiszpania i Niemcy razem wzięte) żyło jedynie 6,5 miliona ludzi. W latach 50 . XX wieku w Libii odkryto złoża ropy naftowej - jak się potem okazało jedne z największych na świecie. Pieniędzy zarobionych na surowcach Kadafi nie wydawał jednak na swoich poddanych, ale oprócz swoich zasilał konta organizacji terrorystycznych. W sondażu instytutu Gallupa z 2010 roku aż 29 proc. młodych Libijczyków było na bezrobociu, a 93 proc. określało swój status jako „trudny do zniesienia” albo „wywołujący cierpienie”20.

Choć dyktatura w Libii była zdecydowanie najbardziej okrutna, a reżim zamknięty i tajemniczy, Hosni Mubarak - prezydent Egiptu, Zine el Abedine Ben Ali - prezydent Tunezji i Muammar Kadafi działali podobnie - za krytykę wobec reżimu dziennikarze i opozycjoniści byli aresztowani i karani, w najlepszym wypadku zastraszani. Niewątpliwa rewolucja w wolności słowa dotknęła więc w wyniku Arabskiej Wiosny każdy z tych

18 J. Klein, Cairo's unsettled spring, dz. cyt.

19 P. Danahar, The new Middle East. The world after the Arab Spring, New York-London-New Delhi-Sydney 2013, s. 21.

20 B. Ghosh, Gaddafi's last stand, „Time” 7.03.2011, s. 24-29. 
krajów. W Libii nie ma już dyktatora, który był w pełni odpowiedzialny za kształt państwa, w krótkim czasie odrodziły się więzi klanowe, represjonowane w czasie rządów reżimu. Rodziny powoli poznają też losy swoich bliskich, którzy przepadli bez wieści w reżimowych więzieniach. Jeszcze w 2011 roku opozycja libijska miała nadzieję, że jeśli Kadafi zostanie obalony, władzę przejmą młodzi Libijczycy, którzy zainicjowali powstanie. To oni mieli tworzyć nowe struktury władzy. Cytowany w magazynie „Time” libijski aktywista polityczny Abdelnabi Yasin mówił w marcu 2011 roku, że młodzi ludzie, którzy dowodzili protestami, „widzą siebie przede wszystkim jako Libijczyków. Ich plemienna tożsamość nie jest tak istotna, jak była dla ich rodziców”21. Nadzieja na nowy porządek w Libii i narodowe zjednoczenie była na początku Arabskiej Wiosny bardzo silna. Ludzie czuli powiew wolności, gdy plakaty z podobizną Kadafiego zniknęły z ulic miast, a słynne muzeum dyktatora $\mathrm{w}$ Trypolisie zostało zrównane $\mathrm{z}$ ziemią.

Zarówno w Libii, jaki i w Egipcie i Tunezji oznaką odwilży było też powstanie setek partii politycznych uczestniczących w wolnych wyborach. Najwyraźniej zmianę widać było w Egipcie, choć protestujący z placu Tahrir uważają to za ironię historii - Bractwo Muzułmańskie, które przez 40 lat władzy Mubaraka działało w podziemiu, zdobyło najwięcej głosów w parlamencie, a kandydat politycznego ramienia bractwa, partii Wolność i Sprawiedliwość - Mohamed Morsi - wygrał pierwsze po Arabskiej Wiośnie wybory prezydenckie. Były to wybory wolne, niezależne i demokratyczne - nie było takich w Egipcie od początku jego starożytnej państwowości.

Oprócz wyborów również tajna policja, tak znienawidzona przez arabskich demonstrantów, przeszła rewolucję (czego domagali się protestujący). Jako osobna instytucja została zdelegalizowana w Tunezji i Libii, a państwowa policja bezpieczeństwa w Egipcie przeżywała dramatyczne wzloty i upadki od 2011 roku. Tortury nie zostały zlikwidowane, niemniej są teraz kontrowersyjne i otwarcie krytykowane. [...] Kluczem do tych zmian jest to, co młodzi Arabowie nazywają godnością (karama), poczuciem własnej autonomii i prawa do wolności człowieka i jego politycznych przekonań, które nie mogą zostać naruszone przez siły bezpieczeństwa ${ }^{22}$.

W artykule o Człowieku Roku 2011 - Protestującym znany amerykański pisarz Kurt Andersen cytuje jednego z młodych demokratów egipskich: „Na końcu będzie dobrze, ponieważ relacja między ludźmi a władzą w Egipcie zmieniła się na zawsze. Ludzie odkryli, że mogą zmienić i zatrzymać władzę, jeśli posunie się za daleko. To odkrycie zmieniło wszystko. Nauczyli się, że mogą zmienić władzę. To jest rewolucja”23.

\section{NOWE MEDIA - NARZĘDZIE ARABSKIEJ REWOLUCJI I DOWÓD POKOLENIOWEJ ZMIANY}

Warto zaobserwować, że wolnościowe protesty w krajach arabskich stały się możliwe dzięki nowym mediom i rozprzestrzenieniu telewizji na niespotykaną dotychczas skalę.

\footnotetext{
${ }^{21}$ B. Ghosh, Gaddafi's last stand, dz. cyt.

22 Zob. J. Cole, The new Arabs, New York-London-Toronto-New Delhi 2014, loc. 120 (Kindle edition).

${ }^{23}$ K. Andersen, The Protester: 2011 Person of the year, „Time” 26.12.2011, s. 82.
} 
Rodzice obecnych 30-latków z krajów arabskich, nawet jeśli działali w opozycji, mieli w zasięgu ręki narzędzia takie jak polscy opozycjoniści odpowiedzialni za pokojową rewolucję 1989 roku: państwową telewizję gloryfikującą władzę i z trudem „łapane” fale arabskich audycji BBC czy Voice of America. W 2011 roku prawdziwą bronią każdego nastolatka był natomiast telefon komórkowy, konto na Twitterze i Facebooku. Bronią, która oddziaływała zaś masowo na pokolenie ich rodziców, była zagraniczna, ale dostępna w każdym z opisywanych krajów telewizja - satelitarny arabski kanał Al Jazeera.

Bobby Ghosh, dziennikarz obserwujący na miejscu rewolucję w Egipcie, ówczesny szef działu zagranicznego „Time” argumentował podczas rozmowy z autorką w Nowym Jorku w maju 2012 roku:

Media społecznościowe nie zorganizowały tej rewolucji. Jeśli cokolwiek, to Al Jazeera stworzyła tę rewolucję. Media społecznościowe były użytecznym narzędziem dla ludzi, by się organizować, nie można ich nie doceniać. A nie można zrobić rewolucji bez organizacji. Media społecznościowe pozwoliły tym młodym ludziom być poza radarem, poza wzrokiem [...] tajnej policji i infrastruktury starego reżimu - oni nie wiedzieli, jak używać mediów społecznościowych. [...] Telewizja satelitarna sprawiła natomiast, że rewolucja zakończyła się sukcesem. Media społecznościowe są wspaniałe, ale ile ludzi w Egipcie ma konto na Facebooku? Ile ludzi w Tunezji ma konto na Twitterze? To naprawdę nieliczna elita. [...] W Libii było ich nawet mniej. A więc liczba ludzi, którzy mogli przekazywać i dostawać wiadomości przez komputery czy smartfony, to maleńka frakcja. Trudno byłoby im przekazywać wiadomości do mas, choćby do farmerów z Delty Nilu, aby powstali, dołączyli się, bez tego nie byłoby przecież rewolucji. Aby to się stało, potrzebna była Al Jazeera, bo nieważne, jak biedny jesteś, czy żyjesz w zakurzonych wioskach Delty Nilu, jeśli jedziesz przez te wioski, widzisz bardzo biednych ludzi, ich domy się rozpadają, ale na każdym z tych domów jest talerz satelitarny ${ }^{24}$.

Niewątpliwie media przyczyniły się do organizacji i mobilizacji rewolucji. Reżim Muamara Kaddafiego podczas rewolucji na pół roku odciął internet w kraju - telefony były jednak wciąż dostępne dla aktywistów, mogli więc komunikować się za pomocą wiadomości tekstowych ${ }^{25}$. Reżim nie odciął także sygnału telewizji satelitarnej.

Siła rażenia mediów społecznościowych i telewizji była niezwykła: do grudnia 2010 ponad 17 proc. tunezyjskiej populacji było na Facebooku; tego samego roku 58 proc. młodych Egipcjan między 18 a 35 rokiem życia miało dostęp do internetu ${ }^{26}$. W 2009 roku 19,5 mln egipskich gospodarstw domowych miało telewizję, a to największy odsetek odbiorców telewizji w Afryce. Z tego około 38 proc. miało swoją satelitę, kolejne 4 proc. miało wykupiony serwis satelitarny ${ }^{27}$.

24 Bobby Ghosh (w czasie arabskiej rewolucji szef działu międzynarodowego w magazynie „Time”) w rozmowie z autorką w Nowym Jorku w maju 2012 roku.

25 J. Cole, The new Arabs, dz. cyt., loc. 313.

26 Arab Social Media Report, Facebook usage: Factors and analysys, Dubai School of Government, January 2011, www.unpan1.un.org/intradoc/groups/public/documents/dsg/unpan044212.pdf (30.04.2014).

27 A sampler of international media and communication statistics, ed. S. Leckner, U. Facht, „Nordic Media Trends” 12, Goteborg 2010, www.nordicom.gu.se/common/publ_pdf/NMT12.pdf, za: J. Cole, The new Arabs, dz. cyt., loc. 321 . 
Jako pierwsi broni w postaci nowych mediów użyli Tunezyjczycy: „Ściągaliśmy wszelkie filmy o reżimie Ben Alego z You Tube i wstawialiśmy na Facebook” powiedziała magazynowi „Time” Rima Aloulou, 26-latka, bezrobotna inżynier. „Po dwóch czy trzech dniach rząd zamknął stronę. Wstawiliśmy film ponownie. To było jak wojna"28. Ponownie warto wspomnieć, że te nowe społeczne przestrzenie stworzyło pokolenie nazywane w krajach arabskich pokoleniem straconym - młodych, bezrobotnych, bez nadziei na lepszą przyszłość, jak wcześniej o nich mówiono. Setki tysięcy użytkowników portali Facebook, Twitter, Instagram, a także blogerów, takich jak Tunisian Girl (atunisiangirl.blogspot.com) uczestniczyło w rewolucji nie tylko na ulicach, ale także online.

Jednym z pierwszych polityków, który wykorzystał siłę mediów społecznościowych do komunikowania się z protestującymi, był Mohamed ElBaradei. Jego profile na Twitterze i Facebooku biły rekordy popularności. Kolejną osobą, która przyczyniła się do prowadzenia rewolucji przez media społecznościowe, był Omar Afifi, były egipski oficer policji, który na długo przed wiosną 2011 stał się aktywistą. W 2008 roku Afifi napisał książkę, w której pisał, jak radzić sobie z brutalnością policji. Książka została w Egipcie zakazana, a Afifiemu grożono śmiercią. Poprosił o azyl polityczny w USA. Stamtąd, wykorzystując media społecznościowe, nadal udzielał rad Egipcjanom, tym razem przez You Tube, Facebooka i Twittera. Kiedy trwały protesty w Tunezji, Afifi opublikował serię filmów na You Tube, szczegółowo instruując Egipcjan w kwestii technik prowadzenia ich własnej rewolucji. Afifi wskazywał, kiedy protestować, gdzie demonstranci powinni się gromadzić, w co powinni się ubierać. Najważniejsze jednak, że były policjant radził, jak przeprowadzać pokojowe protesty ${ }^{29}$.

Media społecznościowe pozwoliły też na rozprzestrzenianie tego rodzaju wiedzy między protestującymi - Egipcjanie sami przyznają, że koledzy z Tunezji wskazali im drogę do pokojowego obalenia dyktatury.

Nowe media były ważną częścią arabskich rewolucji nie tylko ze względu na wartość, jaką miały podczas protestów. Blogi, strony internetowe i konta na Facebooku były pierwszą oznaką wolności słowa, a właściwie dowodem, że władza nie jest w stanie jej dłużej kontrolować, bo - tak jak w Libii - musiałaby odciąć kraj od internetu. Wielu aktywistów działających w internecie na rzecz protestów założyło po ich zakończeniu organizacje pozarządowe, monitorujące sytuację praw człowieka w kraju.

\section{ARABSKa WiOSNA CZY ISLAMSKA ZIMA - JAK FUNDAMENTALIZM ZNISZCZYŁ OSIĄGNIĘCIA ARABSKICH REWOLUCJI}

Walid Phares, politolog i doradca wielu amerykańskich polityków, analityk m.in. stacji Fox News napisał we wstępie do swojej książki: „ironią Arabskiej Wiosny jest

28 V. Walt, Tunisia's nervous neighbors watch the Jasmine Revolution, dz. cyt.

29 N. Eltantawy, J. B. Wiest, Social media in the Egyptian revolution: reconsidering resource mobilization theory, „International Journal of Communication”, www.ijoc.org/index.php/ijoc/article/view/1242/597 (30.06.2014). 
mutacja kwitnącego ruchu społecznego w pierwszych miesiącach 2011 roku do pełnej islamskiej zimy 2013"30.

Rzeczywiście - analizując obecną sytuację w krajach arabskich, trudno oprzeć się wrażeniu, jakie organizatorzy pierwotnych protestów mieli już wiosną 2012 roku - że islamiści „ukradli” im rewolucję. Walid Phares argumentuje ten dramatyczny zwrot społeczeństw arabskich w stronę islamskiego fundamentalizmu przede wszystkim brakiem poparcia dla arabskich liberałów ze strony rządu amerykańskiego i innych państw zachodnich. Najbardziej dramatycznego zwrotu pokojowej rewolucji doświadczyła Libia. Mocno podzielony plemiennie kraj o bezcennych złożach ropy boryka się $\mathrm{z}$ wewnętrznym chaosem. Zamiast demokratycznego rządu, o którym marzyli dowódcy rebeliantów w Bengazi, jest rząd, który w grudniu 2013 roku wprowadził w Libii prawo szariatu. Amerykańskie bombowce pomogły obalić Kaddafiego, ale gdy odleciały, próżnię władzy zapełnili szybko islamscy fundamentaliści, destabilizując kruche wciąż struktury państwowe. Bardzo wyraźnym i tragicznym początkiem antyzachodnich działań na wielką skalę był zamach na ambasadę amerykańską w Libii, w którym jedną z czterech ofiar śmiertelnych był ambasador Christopher Stevens - osoba wyjątkowo oddana wprowadzaniu przemian demokratycznych w Libii.

Mimo problemów targających krajem Libijczycy starali się wciąż być pełni nadziei na zmiany. Cytowany w reportażu Abigail Hauslohner Saad Abdel Ghader, mieszkaniec Bengazi chwalił się: „Nic nie zmieniło się w Egipcie, gdzie wojsko wciąż jest u władzy. A tu pozbyliśmy się wszystkiego!”. Ale to oznaczało także, że Libia musi zaczynać od zera. Już wtedy dawały o sobie znać regionalne bojówki, które zatrzymały dla siebie broń odebraną lojalistom. Plemiona zaczęły mówić o autonomii, wciąż niepodzielone były złoża ropy. Ludność wcześniej popierająca reżim bała się teraz zemsty byłych rebeliantów ${ }^{31}$.

Nie tylko Libia doświadczała efektów próżni władzy, jaka pojawiła się po obaleniu dyktatur. W postrewolucyjnych Egipcie i Tunezji opozycja demokratyczna podzieliła się tak bardzo, że liczba wystawionych przez nich kandydatów nie była w stanie przebić w głosowaniu kandydatów partii islamskich, które - silne i zjednoczone przez wiele lat działania w podziemiu - teraz pokazały swoją siłę. Należy podkreślić, że zachodnie media nie były źle nastawione do zwycięzców wyborów - islamskiej partii Nahda w Tunezji czy Bractwa Muzułmańskiego w Egipcie. Dopiero gdy w Tunezji dokonano głośnych zamachów na liderów opozycji, a prezydent Morsi w Egipcie zaczął tylnymi drzwiami wprowadzać szariat do konstytucji, w relacjach medialnych pojawił się niepokój.

W badaniach przeprowadzonych w temacie przemian społecznych w Arabskiej Wiośnie interesujące jest kalendarium ich pozytywnego i negatywnego opisywania przez magazyn „Time” . Do sierpnia 2012 roku ani jeden artykuł nie opisywał przemian społecznych w krajach Arabskiej Wiosny negatywnie. Pierwszym powodem do głębszej i mniej entuzjastycznej analizy wydarzeń i przemian społecznych na Bliskim Wschodzie był atak na ambasadę amerykańską w Bengazi. Bezpośrednim powodem ataku był wyprodukowany w Stanach Zjednoczonych film klasy B, o niewielkiej wartości artystycznej i technicznej, przedstawiający w złym świetle proroka Mahometa. Wywołał on protesty i zamieszki w całym świecie arabskim. Podczas jednego z takich protestów ostrzelana została ambasada amerykańska w Bengazi. Również w Egipcie doszło do krwawych

30 W. Phares, Lost spring - U.S. policy in the Middle East and catastrophes to avoid, New York 2014, s. 3.

31 A. Hauslohner, Hope among the ruins, „Time” 4.06.2012, s. 40. 
protestów przed ambasadą amerykańską w Kairze. Młodzi Arabowie wyszli na ulice w obronie religii. Jak się potem okazało - w protestach uczestniczyła znaczna część fundamentalistów islamskich, a zamach na ambasadę w Libii zorganizowało lokalne ramię Al-Qaidy.

24 września 2012 roku szef działu zagranicznego magazynu „Time” Bobby Ghosh pisał o kryzysie wartości protestujących Arabów, nazywając ich „agentami oburzenia”. Krytykował też rządy Libii i Egiptu za niewłaściwe reakcje na protesty: „Wciąż nie przywykli do sprawowania władzy, nie są pewni, jak radzić sobie z wściekłymi demonstracjami, szczególnie gdy napędzani są przez potężne grupy religijne i polityczne. Tendencją było tu albo odwrócenie wzroku, albo nadzieja, że demonstrantom zabraknie pary" ${ }^{32}$.

Publicyści pytali także, gdzie teraz jest Wael Ghonim? „Gdzie jest on i tysiące takich jak on, kiedy wolność w Egipcie znów jest zagrożona?”. Fareed Zakaria pyta także: „Czy wobec zagrożenia wolności przez pełen przemocy motłoch i nietolerancyjne tłumy ktokolwiek wstanie, by jej bronić?"33.

Protesty „W obronie Islamu” przyszły w momencie kluczowym dla Bliskiego Wschodu - ludzie widzieli już, że rewolucja oprócz wolnych wyborów i względnej wolności słowa nie przyniosła zamierzonych efektów - ceny wciąż były wysokie, gospodarka nie podniosła się jeszcze ze strat spowodowanych protestami (choćby rezygnacją turystów z Egiptu i Tunezji jako wakacyjnych destynacji), a młodzi wciąż byli bez pracy. W Tunezji rząd zaoferował młodym absolwentom wyższych uczelni zasiłek w wysokości 100 dinarów miesięcznie i pomoc socjalną w postaci dofinansowania racji żywnościowych, ale liczba miejsc pracy dla wykwalifikowanych pracowników wciąż nie wzrosła ${ }^{34}$. W Egipcie sytuacja też wyglądała nie inaczej niż w czasie, gdy młodzi na placu Tahrir obalali prezydenta Mubaraka - 60 proc. populacji było przed 30 rokiem życia, 25 proc. z nich było bezrobotnych.

Na podatny grunt społecznej frustracji trafiła ideologia islamistów. Wolność słowa, wywalczona podczas protestów w 2011 roku, dała wolność wyrażania opinii także im - fundamentalistom.

Zauroczeni przez wzniosłe idee rewolucji, zachodni felietoniści wydawali się nie zauważać, jakie zagrożenia czyhają w krajach porwanych Arabską Wiosną. Jednym z niewielu tekstów w analizowanym magazynie "Time”, który wcześnie wskazywał na zagrożenia, jest artykuł Joe Kleina z marca 2011 roku. Felietonista „Time” już wtedy pytał, czy nie bardziej niż interwencja militarna w Libii opłacałoby się dofinansowanie egipskich demokratów:

Rewolucja w Egipcie się nie skończyła, ledwo się zaczęła. Wojsko wciąż jest u władzy, było zresztą przez ostatnie 60 lat. A kryzys przecież nadchodzi, klasyczny kryzys wzrastających oczekiwań: co stanie się za trzy miesiące, jeśli życie nie zmieni się dla setek tysięcy młodych ludzi, którzy wyszli na ulice Kairu? ${ }^{35}$.

32 B. Ghosh, Flash Point, „Time” 24.09.2012, s. 33.

33 F. Zakaria, A Moment for moderates, „Time” 1.10.2012, s. 24.

34 www.crisisgroup.org/en/multimedia/podcasts/2012/tunisia-lawrence-economic-challenges.aspx (14.08.2014).

35 J. Klein, Middle East Priority: a regional infrastructure bank, „Time” 17.03.2011, www.content.time.com/ time/magazine/article/0,9171,2059609,00.html (30.06.2014). 
Jednak w 2012 roku fundamentaliści na dobre zadomowili się w krajach Arabskiej Wiosny. Grupy takie jak egipscy salafici zyskali na pierwotnych protestach znacznie więcej niż demonstranci na placu Tahrir - zostali wypuszczeni z więzień, weszli do życia politycznego, założyli gazety, radia i stacje telewizyjne.

Kiedy prezydent Mohamed Morsi nie dał im obiecanych miejsc w swoim gabinecie, wyszli na ulice, by pokazać, jaką mają siłę. Czy powinni skorzystać z nowych wolności i wyrazić siebie pokojowo, czy użyć znanych narzędzi obrazy i religijnej wściekłości, by przeszkodzić transformacji w demokrację i zbudować swoją własną władzę polityczną? To, jak salafici odpowiedzą na to pytanie - i jak odpowiedzą umiarkowane partie muzułmańskie - może zdeterminować los Arabskiej Wiosny ${ }^{36}$.

Jesienią 2012 roku prasa nie wydawała się też widzieć zagrożenia w demokratycznie wybranych rządach Egiptu i Tunezji - prezydent Egiptu wywodzący się z Bractwa Muzułmańskiego znalazł się nawet na okładce magazynu „Time” 10 grudnia 2012 roku. Tytuł okładkowy to Mohamed Morsi - najważniejszy człowiek na Bliskim Wschodzie. Morsi zyskał uznanie Zachodu, negocjując porozumienie pokojowe w Gazie i zyskując dla Egiptu pożyczki Międzynarodowego Funduszu Walutowego. 31 grudnia „Time” nagrodził Morsiego 4 miejscem w plebiscycie na Człowieka Roku. W Egipcie ten sam prezydent nie był jednak popularny - jednym ze swoich dekretów postawił się ponad sądami i władzą wojskową, do konstytucji chciał zaś wprowadzić prawa zgodne z prawem szariatu. Ale co najważniejsze w niniejszej analizie - prezydent Morsi stał się symbolem zupełnej dysfunkcyjności struktur demokratycznych w Egipcie. Egipcjanie, którym nie spodobały się kroki wybranego przez nich prezydenta, znów wyszli na ulice, żądając jego ustąpienia. Wobec słabości prezydenta i kruchości systemu wojskowa rada pod przywództwem ministra obrony generała Abdela Fataha Al-Sisiego obaliła prezydenta. Protestując, Egipcjanie doprowadzili do władzy tych samych ludzi, którzy rządzili Egiptem przed Arabską Wiosną. Wobec sympatii Zachodu do obalonego prezydenta i relacje medialne bezlitośnie krytykowały niedojrzałość wywalczonej demokracji:

Przytulając się do armii po to, by obaliła Morsiego, jego polityczni oponenci porzucili demokratyczny proces, dla którego wielu z nich ryzykowało życiem dwa i pół roku temu. Z taką popularnością, jaką miał, zamach stanu stanowi precedens dla zmiany władzy: nie przy urnach wyborczych, ale przez motłoch. I przesyła to jasny sygnał islamistom na całym świecie, że wybory są dokładnie tym, czym ekstremiści zawsze je nazywali: bezsensem ${ }^{37}$.

Mohammed Badie, najwyższy przywódca Bractwa Muzułmańskiego, natychmiast wezwał swoich zwolenników do obrony każdego placu w Egipcie - cytowany powyżej Karl Vick ostrzega, że właśnie w takim wojennym kierunku zmierza Egipt, jeśli nie przesunie prowadzenia polityki „Z gorącego słońca do gabinetów”38.

Egipcjanie nie zdali egzaminu z demokracji, co uwidocznione zostało na okładce magazynu „Time” z 22 lipca 2013 roku: jedno zdjęcie tłumu na placu Tahrir zostało

36 B. Ghosh, The rise of the Salafis, „Time” 8.10.2012, s. 48

37 K. Vick, Street rule, „Time” 22.07.2013, s. 30.

38 K. Vick, Street rule, dz. cyt., s. 30. 
podpisane dwoma tekstami: z lewej strony „Najlepsi Protestujący Świata”, z prawej: „Najgorsi Demokraci Świata”. Ówczesny redaktor naczelny Richard Stengel napisał w swoim edytorialu:

Częścią demokracji jest czasem głosowanie na kandydatów, którzy nie okażą się tacy, jakich się spodziewaliśmy, albo takich, którzy nas zawiodą. I w demokracji lekiem na bycie zawiedzionym po jednych wyborach są generalnie kolejne wybory. To nie jest to, co widzieliśmy w Egipcie. Ale demokracja wymaga czasu.

Czas pokazał jednak, że Egipt pogrąża się w represjach, jakie dotykały ludzi przed rozpoczęciem Arabskiej Wiosny. 4 czerwca 2013 roku 43 pracowników organizacji pozarządowych, w tym wielu Amerykanów, zostało skazanych na kary więzienia za rzekome nielegalne finansowanie swoich organizacji. Sąd nakazał także zamknięcie pięciu organizacji: Freedom House, International Democratic Institute, National Democratic Institute, International Center for Journalists, a także niemieckiej Fundacji Konrada Adenauera. Zasądzono także konfiskatę ich majątków ${ }^{39}$. Takich represji organizacje te nie doznały nawet za rządów Hosni Mubaraka.

Wielu obrońców praw człowieka nie było zatem już w Egipcie, kiedy pacyfikowano pokojową okupację placu Rabi’a - okupację zorganizowaną przez zwolenników Bractwa Muzułmańskiego wzywających do powrotu do władzy prezydenta Mohameda Morsiego. Według raportu Human Rights Watch 14 sierpnia 2013 roku, począwszy od godziny 7 rano, siły rządowe z premedytacją zabiły 817 osób, a ich liczba najprawdopodobniej przekracza tysiąc. Ofiary były zabijane z lądu i z powietrza - do pacyfikacji okupantów użyto helikopterów, zatrudnieni zostali także snajperzy zabijający rannych w drodze do szpitala. Masowe i według Human Rights Watch doskonale zaplanowane morderstwa zwolenników Bractwa Muzułmańskiego trwały od 30 czerwca 2013 roku, jednak wydarzenia z 14 sierpnia, zwane już „egipskim Tiananmen”, były największym masowym pogwałceniem praw człowieka. Pracownicy Human Rights Watch nazywają je nawet zbrodnią przeciwko ludzkości i we wnioskach do raportu wzywają środowisko międzynarodowe do powołania komisji przy ONZ do zbadania zbrodni egipskich władz ${ }^{40}$. Keneth Roth, który z ramienia Human Rights Watch 10 sierpnia 2014 roku miał dostarczyć raport do władz egipskich, nie został wpuszczony na teren Egiptu „ze względów bezpieczeństwa”"

Takiego biegu wydarzeń nie przewidzieli autorzy artykułów do magazynu „Time” w analizowanym okresie. W artykułach, w których autor wyrażał opinię o przyszłości danego kraju w kontekście społecznym, optymizm i niepokój wyrażono po równo w 12 artykułach, neutralność zaś - wyważenie pomiędzy dobrymi a złymi konsekwencjami rewolucji - w 34 artykułach. Przy czym, przypomnijmy, do sierpnia 2012 roku sytuacja społeczna w krajach Bliskiego Wschodu była opisywana wyłącznie pozytywnie.

Krajem, który dziś opisywany jest jako ostatni bastion ideałów arabskich rewolucji, jest Tunezja. W porównaniu do krwawych pacyfikacji w Egipcie, wojny domowej w Syrii i cha-

39 www.edition.cnn.com/2013/06/04/world/africa/egypt-ngos/index.html (25.07.2014)

40 www.hrw.org/sites/default/files/related_material/egypt0814_brochure_web_0.pdf (12.08.2014).

${ }^{41}$ www.foreignpolicy.com/articles/2014/08/12/egypts_tiananment_cairo_sisi_rabaa_square_massacre_human_rights_watch?utm_source=Sailthru\&utm_medium=email\&utm_term=Flashpoints\&utm_campaign=2014_FlashPoints\%20\%28Manual\%29 (12.08.2014). 
osu w Libii, Tunezja w największym stopniu stara się dopełnić obietnic Arabskiej Wiosny. 2013 rok zaznaczył się jednak w Tunezji kolejną falą protestów wywołanych zabójstwem dwóch prominentnych polityków opozycyjnych. Na początku 2014 roku, kiedy sytuacja zaczęła się ponownie stabilizować, w kraju przyjęto konstytucję, która, choć daleka od ideałów, daje na przykład spore prawa kobietom. Nie zakazała jednak kary śmierci, co dla wielu aktywistów byłoby oznaką prawdziwej politycznej i społecznej odwilży ${ }^{42}$. Sytuacja społeczna ani materialna Tunezyjczyków nie doczekała się jednak poprawy, a przecież tego właśnie domagano się pierwotnie - czyli po samobójczej śmierci Mohameda Bouazizi. „Absolutnie nic się nie zmieniło. Była krew na ulicach, walczyliśmy i nic nie dostaliśmy w zamian” mówił redakcji Huffington Post mieszkaniec miasta Sidi Bouzid w trzecią rocznicę rewolucji ${ }^{43}$.

\section{PodsumoWANIE I WNIOSKI}

Zachodni dziennikarze wiele miejsca w swoich analizach poświęcili zmianom społecznym w krajach Arabskiej Wiosny. W 2011 roku protesty, rozprzestrzeniające się niczym wirus w krajach Bliskiego Wschodu, były dowodem, że społeczeństwa krajów arabskich nauczyły się pokojowo walczyć o swoje prawa. I że nie boją się o nie walczyć. Spektakularne rezygnacje z urzędów prezydentów Zine El Abedine ben Alego w Tunezji i Hosni Mubaraka w Egipcie były zaś dowodem na to, że uciskane i zniewolone społeczeństwa powstały i dzielnie wywalczyły nowy porządek. Niemal rok po rozpoczęciu fali rewolucji w Libii, wyniszczonej wojną domową i nalotami NATO, ludzie mieli nadzieję, że po obaleniu dyktatora czeka ich czas normalności i stabilizacji. Po pierwszej fali protestów i zwycięstwie nad tyranią społeczeństwa krajów Arabskiej Wiosny żyły w euforii rewolucji - euforię tę podzielał magazyn „Time”. Mimo zwycięstw wyborczych partii islamskich tygodnik przedstawiał pozytywny obraz społecznej rewolucji, co odzwierciedlała liczba artykułów pozytywnie i neutralnie odwołujących się do przemian społecznych na Bliskim Wschodzie - do ataku na ambasadę w Bengazi w sierpniu 2012 roku ani jeden artykuł nie oceniał negatywnie bliskowschodnich przemian społecznych, mimo że wybory w każdym z „wyzwolonych” krajów wygrywały partie islamskie. Dziś, w 2014 roku, wiemy już jednak, że w miejsce znienawidzonych upadłych reżimów weszły nowe - i to na życzenie tych samych społeczeństw, które domagały się demokratycznych zmian w swoich krajach. Powody takiego przebiegu transformacji wymagają osobnej analizy politologicznej, warto wymienić jednak kilka z nich: transformacja wymaga dużego wsparcia silnej demokracji, a tego - choćby ze strony Stanów Zjednoczonych - zabrakło. Preferując politykę „pozostawienia tego, co arabskie, arabskiej ulicy”, państwa zachodnie pozwoliły na powstanie ogromnej próżni władzy, szybko zapełnionej przez fundamentalistów, dobrze przygotowanych do przejęcia rządów. Przygotowywali się oni do tego przez cały okres trwania protestów, bo w samej rewolucji nie uczestniczyli. Przemianom demokratycznym i budowie społeczeństwa obywatelskiego doskwierał także bardzo brak wyraźnych liderów - młodzi ludzie biegli w mediach społecznościowych i ich rodzice oglądający Al Jazeerę nie byli

42 www.aljazeera.com/indepth/features/2014/01/tunisia-arab-spring-three-years-20141146353728616. html (14.08.2014).

43 www.huffingtonpost.com/2013/12/18/tunisia-revolution-arab-spring_n_4462064.html (14.08.2014). 
przygotowani na przejęcie władzy w krajach o tak skomplikowanej strukturze społeczno-politycznej. Liderzy, którzy mogliby podjąć się tego zadania, albo nie podjęli próby, albo nie mieli wystarczającej charyzmy (i środków), by stanąć na czele potencjalnych nowych władz. Obserwując obecną sytuację na Bliskim Wschodzie, między innymi masakrę chrześcijan i jazydów na terenach samozwańczego kalifatu islamskiego, prorocze okazują się słowa publicysty „Time” z października 2011 roku: „Arabów zainspirował przykład innych Arabów. Co ma znaczenie w świecie arabskim, ma znaczenie dla Arabów. I dlatego też ma to znaczenie dla nas wszystkich" ${ }^{4}$. Konsekwencje braku zachodniego wsparcia dla prodemokratycznych prekursorów Arabskiej Wiosny okazują się dziś katastrofalne nie tylko dla społeczeństw Bliskiego Wschodu, a dla całego regionu i - przez znaczenie tego regionu - dla świata w perspektywie globalnej. Po wstępnej fazie rewolucji w procesie przemian społecznych Bliski Wschód powrócił do stanu sprzed Arabskiej Wiosny (Egipt), a w kilku przypadkach (Libia, Syria, Irak) pogrążył się w chaosie na niespotykaną w ostatnich latach skalę. Trwałe zmiany wymagałyby wieloletniego zaangażowania w regionie silnych demokracji, takich jak Stany Zjednoczone. Proces ten jest zaś uzależniany przez mocarstwa od ich długofalowych interesów.

\section{LITERATURA}

Abouzeid R., Postcard: Sidi Bouzid. Visiting the birthplace of the Jasmine Revolution, "Time” 7.02.2011, s. 8.

Ajami F., The sorrows of Egypt, Foreign Affairs 1995.

Andersen K., The Protester: 2011 Person of the year, „Time” 26.12.2011, s. 82.

Anderson L., Demystifying the Arab Spring: parsing the differences between Tunisia, Egypt and Libya, Foreign Affairs 2011.

Arab Social Media Report, Facebook usage: Factors and analysys, Dubai School of Government, January 2011, www.unpan1.un.org/intradoc/groups/public/documents/dsg/unpan044212.pdf (30.04.2014).

Arabska Wiosna rok później, „Krakowskie Studia Międzynarodowe” nr 1 (9) 2012.

Arieff A., Political transition in Tunisia, Congressional Research Service, 15.04.2011.

Briefing, The moment, „Time” 21.02.2011, s. 17.

Cole J., The new Arabs, New York-London-Toronto-New Delhi 2014, loc. 313 (kindle edition).

Danahar P., The new Middle East, New York 2013.

Danecki J., Sulowski S., Bliski Wschód coraz bliżej, Warszawa 2011.

ElBaradei M., Wael Ghonim - spokesman of a revolution, „Time”21.04.2011, www.content.time. com/time/specials/packages/article/0,28804,2066367_2066369_2066437,00.html (30.04.2014).

Elliott M., Learn to love the revolution, „Time” 7.03.2011, s. 30.

Eltantawy N., Wiest J. B., Social media in the Egyptian revolution: reconsidering resource mobilization theory, „International Journal of Communication” www.ijoc.org/index.php/ijoc/article/ view/1242/597 (30.06.2014).

Fale Tunisami: kontestacja arabska w latach 2010-2013, red. R. Potocki, M. Piskorski, W. Hładkiewicz, Warszawa 2014.

Gelvin J. L., The Arab uprisings - what everyone needs to know, New York 2012.

Gelvin J. L., The modern Middle East - a history, Oxford-New York 2011.

${ }^{44}$ M. Elliott, Learn to love the revolution, „Time” 7.03.2011, s. 30-35. 
Ghonim W., Revolution 2.0, Boston-New York 2013.

Ghosh B., Flash point, „Time” 24.09.2012, s. 33.

Ghosh B., Gaddafi's last stand, „Time” 7.03.2011, s. 24.

Ghosh B., Rage rap and revolution, „Time” 28.02.2011, s. 33.

Ghosh B., Revolution delayed, „Time” 21.02.2011, s. 35.

Ghosh B., The revolutionaries: how a loose coalition of veteran activists and rookie protesters combined to create the Middle East's most unusual uprising, „Time” 14.02.2011, s. 38.

Ghosh B., The Rise of the Salafis, „Time” 8.10.2012, s. 48.

Hauslohner A., Hope among the ruins, „Time” 4.06.2012, s. 40.

Hauslohner A., On the Arab street. Rage is contagious, „Time” 7.02.2011, s. 36.

Indyk M., Back to the bazaar, Foreign Affairs 2002.

International Crisis Group, Tunisia: confronting social and economic challenges,

Jankowski D., Po „arabskiej wiośnie” - „zima” dla europejskiej obrony?, „Bezpieczeństwo Narodowe” 2 (2011), nr 18, s. 57.

Jaskiernia A., Media masowe $w$ demokratycznych procesach wyborczych. Standardy europejskie i uwarunkowania ich realizacji, Warszawa 2008.

Klein J., Cairo's unsettled spring, „Time” 18.04.2011.

Klein J., Middle East priority: a regional infrastructure bank, „Time” 17.03.2011, www.content.time. com/time/magazine/article/0,9171,2059609,00.html (30.06.2014).

Lisowska-Magdziarz M., Analiza zawartości mediów. Przewodnik dla studentów, wersja 1.1., „Zeszyty Wydziałowe" Uniwersytet Jagielloński, Kraków, 2004.

Parzymies S., Aspekty wewnętrzne i międzynarodowe „Arabskiej Wiosny”, „Stosunki Międzynarodowe - International Relations" 44 (2011) nr 3-4, s. 35.

Phares W., The lost spring, U.S. policy in the Middle East and catastrophes to avoid, New York 2014.

Stengel R., The Protester - editors note, „Time” 26.12.2011, s. 53.

Stosunki międzynarodowe na Bliskim Wschodzie po Arabskiej Wiośnie, Krakowskie Studia Międzynarodowe" nr 3 (10) 2013.

The Arab Spring, ed. B. Przybylska-Maszner, Poznań 2011.

The new Arab revolt (praca zbiorowa), New York 2011.

The White House, Office of the Press Secretary, Remarks by the President on Egypt, 11.02.2011, www.whitehouse.gov/the-press-office/2011/02/11/remarks-president-egypt.

Vick K., Street rule, „Time” 22.07.2013, s. 30.

Walt V., Tunisia's nervous neighbors watch the Jasmine Revolution, „Time” 31.01.2011, s. 24.

www.aljazeera.com/indepth/features/2014/01/tunisia-arab-spring-three-years-20141146353728616. html (14.08.2014).

www.content.time.com/time/magazine/article/0,9171,2063873,00.html (30.06.2014).

www.crisisgroup.org/en/multimedia/podcasts/2012/tunisia-lawrence-economic-challenges.aspx (14.08.2014).

www.edition.cnn.com/2013/06/04/world/africa/egypt-ngos/index.html (25.07.2014).

www.edition.cnn.com/2014/06/08/world/africa/egypt-presidential-election (11.08.2014).

www.foreignpolicy.com/articles/2014/08/12/egypts_tiananment_cairo_sisi_rabaa_square_ massacre_human_rights_watch?utm_source=Sailthru\&utm_medium=email\&utm _ term=Flashpoints\&utm_campaign=2014_FlashPoints\%20\%28Manual\%29 (12.08.2014).

www.hrw.org/sites/default/files/related_material/egypt0814_brochure_web_0.pdf (12.08.2014). www.huffingtonpost.com/2013/12/18/tunisia-revolution-arab-spring_n_4462064.html (14.08.2014).

Zakaria F., A moment for moderates, „Time” 1.10.2012, s. 24.

Zakaria F., The revolution, „Time” 14.02.2011, s. 29.

Zakaria F., Why it's different this time, „Time” 28.02.2011, s. 28. 